\title{
Responses of nitrogen metabolism and seed nutrition to drought stress in soybean genotypes differing in slow-wilting phenotype ${ }^{1}$
}

\section{Nacer Bellaloui ${ }^{1 *}$, Anne M. Gillen ${ }^{1}$, Alemu Mengistu' ${ }^{2}$, Hirut Kebede ${ }^{3}$, Daniel K. Fisher ${ }^{3}$, James R. Smith ${ }^{1}$ and Krishna N. Reddy ${ }^{3}$}

${ }^{1}$ Crop Genetics Research Unit, US Department of Agriculture - Agricultural Research Service, Stoneville, MS, USA

${ }^{2}$ Crop Genetics Research Unit, US Department of Agriculture - Agricultural Research Service, Jackson, TN, USA

${ }^{3}$ Crop Production Systems Research Unit, US Department of Agriculture - Agricultural Research Service, Stoneville, MS, USA

\section{Edited by:}

Yuriko Osakabe, RIKEN Plant

Science Center, Japan

Reviewed by:

Nabil I. Elsheery, Tanta Univeristy,

Egypt

Lam-Son Tran, RIKEN Center for

Sustainable Resource Science,

Japan

${ }^{*}$ Correspondence:

Nacer Bellaloui, Crop Genetics

Research Unit, US Department of Agriculture - Agricultural Research Service, 141 Experiment Station Road, Stoneville, 38776, MS, USA e-mail:nacer.bellaloui@ars.usda.gov
Recent advances in soybean breeding have resulted in genotypes that express the slow-wilting phenotype (trait) under drought stress conditions. The physiological mechanisms of this trait remain unknown due to the complexity of trait $\times$ environment interactions. The objective of this research was to investigate nitrogen metabolism and leaf and seed nutrients composition of the slow-wilting soybean genotypes under drought stress conditions. A repeated greenhouse experiment was conducted using check genotypes: NC-Roy (fast wilting), Boggs (intermediate in wilting); and NTCPR94-5157 and N04-9646 (slow-wilting, SLW) genotypes. Plants were either well-watered or drought stressed. Results showed that under well-watered conditions, nitrogen fixation (NF), nitrogen assimilation (NA), and leaf and seed composition differed between genotypes. Under drought stress, NF and NA were higher in NTCPR94-5157 and N04-9646 than in NC-Roy and Boggs. Under severe water stress, however, NA was low in all genotypes. Leaf water potential was significantly lower in checks $(-2.00 \mathrm{MPa})$ than in the SLW genotypes $(-1.68 \mathrm{MPa})$. Leaf and seed concentrations of $\mathrm{K}, \mathrm{P}, \mathrm{Ca}, \mathrm{Cu}, \mathrm{Na}$, B were higher in SLW genotypes than in the checks under drought stress conditions. Seed protein, oleic acid, and sugars were higher in SLW genotypes, and oil, linoleic and linolenic acids were lower in SLW genotypes. This research demonstrated that $\mathrm{K}, \mathrm{P}, \mathrm{Ca}, \mathrm{Cu}, \mathrm{Na}$, and $\mathrm{B}$ may be involved in SLW trait by maintaining homeostasis and osmotic regulation. Maintaining higher leaf water potential in NTCPR94-5157 and N04-9646 under drought stress could be a possible water conservation mechanism to maintain leaf turgor pressure. The increase in osmoregulators such as minerals, raffinose, and stachyose, and oleic acid could be beneficial for soybean breeders in selecting for drought stress tolerance.

\section{Keywords: soybean, seed nutrition, seed composition, slow-wilting, drought tolerance}

\section{INTRODUCTION}

Soybean is a major crop in the world and a source of protein, oil, sugars, and minerals. Water deficit is an important environmental stress factor that negatively impacts crop growth and development, leading to yield loss and poor seed quality (Smith et al., 2008; Mengistu et al., 2010; Bellaloui et al., 2012; Furlan et al., 2012). Water deficit triggers physiological and biochemical responses such as: (a) cellular dehydration, causing osmotic stress and removal of water from the cytoplasm into the extracellular space, lowering turgor pressure and cytosolic and vacuolar volumes (Bartels and Sunkar, 2005); (b) accumulation of compatible solutes such as sugars (sucrose, hexoses, and sugar alcohols such as mannitol, sorbitol, and isotol) (Gilmour et al., 2000

\footnotetext{
${ }^{1}$ Mention of trade names or commercial products in this publication is solely for the purpose of providing specific information and does not imply recommendation or endorsement by the U.S. Department of Agriculture
}

Streeter et al., 2001; Taji et al., 2002), amino acids such as proline, glycine, and betaine to maintain turgor and stabilize proteins and cell structures (Yancey et al., 1982; Burg et al., 1996); (c) accumulation of specific ions such as $\mathrm{K}$ to increase osmotic pressure and regulate stomatal opening (Bartels and Sunkar, 2005); (d) expression of stress-induced genes (Bartels and Sunkar, 2005); (e) increases in hormones such as abscisic acid; and (f) stimulation of signaling components such as protein kinases and phosphatases, $\mathrm{Ca}^{2+}, \mathrm{Cl}^{-}, \mathrm{Na}^{+}, \mathrm{K}^{+}$, and reactive oxygen species (ROS) (Knight et al., 1997; Schroeder et al., 2001; Furlan et al., 2012).

Nitrogen fixation and assimilation are negatively affected by drought. Nitrogen metabolism in legumes is a result of both symbiotic $\mathrm{N}_{2}$ fixation and mineral $\mathrm{N}$ assimilation processes. Atmospheric $\mathrm{N}_{2}$ is fixed by the enzyme nitrogenase in the bacteroids of nodules (Kanayama et al., 1999), and nitrate reduction (assimilation) (NR) is catalyzed by the enzyme nitrate reductase (NR). Both NR and nitrogenase enzymes coexist in nodules 
competing for reductant (reducing power) (Caba et al., 1995). Drought affects both nitrogen fixation (NF) and nitrogen assimilation (NA) by inhibiting nitrogenase and nitrate reductase, although nitrogenase is more sensitive to drought stress than nitrate reductase (Purcell and King, 1996). Mechanisms involved in the physiological response of nitrogen fixation to drought have been previously reported and included carbon shortage, nodule carbon metabolism, oxygen limitation, and feedback of nitrogen fixation products (Serraj et al., 1999; Serraj, 2003) such as amides (mainly asparagine) and ureides (allantoin and allantoic acid), both exported to the shoot via the xylem (Schubert et al., 1995).

Mineral nutrition in plants is essential for plant growth, development, production, and seed quality. Deficiencies in minerals due to abiotic stress such as drought at any plant stage result in yield loss and poor seed quality. Physiological and biochemical roles of macro-nutrients such as $\mathrm{S}, \mathrm{Ca}, \mathrm{K}, \mathrm{Mg}$, and $\mathrm{P}$ or micronutrients such as $\mathrm{Fe}, \mathrm{B}$, and $\mathrm{Zn}$ have been previously reported for plants (Mengel and Kirkby, 1982; Marschner, 2012). However, the physiological and biochemical roles of mineral nutrients in slow-wilting genotypes under drought tolerance have not been well investigated.

Recent advances in soybean breeding resulted in selection of slow-wilting soybean genotypes with drought tolerance. Slowwilting is defined as a delayed wilting response to decreased soil moisture as compared to an average soybean cultivar. However, mechanisms involved in plant responses to drought stress are not well understood (Lawlar and Cornic, 2002; Hufstetler et al., 2007; Charlson et al., 2009; King et al., 2009). Evidence showed that the wilting response (fast or slow/delayed wilting) of soybean genotypes to drought stress differ (Sloane et al., 1990), and slow-wilting genotypes have the ability to conserve soil moisture (Fletcher et al., 2007; King et al., 2009; Ries et al., 2012) by lowering transpiration rate to maintain turgor pressure compared with conventional fast-wilting genotypes (Charlson et al., 2009). King et al. (2009) reported that volumetric soil water content was greater for slow-wilting than for fast-wilting genotypes in a field experiment, but wilting responded similarly for both genotypes. In a growth chamber experiment, transpiration declined similarly in response to drought stress for fast- and slow-wilting genotypes, indicating that more than one mechanism is involved in slow-wilting (King et al., 2009). Also, Sloane et al. (1990), using a slow-wilting genotype PI 416937 and "fastwilting” cultivar Forrest, found that water stress reduced leaf water potential equally for both genotypes, but that PI 416937 maintained lower levels of solute potential and higher pressure potential and relative water content than Forrest. They suggested that under water stress PI 416937 may accumulate more solutes in leaves than Forrest, and concluded that PI 416937 may be an important source of drought tolerance for breeding programs.

In spite of the extensive research on drought tolerance, identification of physiological and biochemical traits involved with the slow-wilting trait has not been fully explored, and may involve several mechanisms (King et al., 2009). Therefore, the objective of this research was to evaluate nitrogen metabolism (nitrogen fixation and nitrate assimilation) and identify possible roles of sugars and minerals in unique genotypes that have a slow-wilting trait.
Our hypothesis was that if drought tolerance in the slow-wilting genotypes leads to conserving soil moisture under drought tolerance, then leaf and seed nutrients involved in osmoregulation components would respond differently from those grown under well-watered conditions.

\section{MATERIALS AND METHODS GROWTH CONDITIONS}

A repeated greenhouse experiment was conducted at USDA-ARS, Crop Genetics Research Unit. Soybean genotypes in maturity group (MG) VI and differing in wilting were used. Genotypes were: NC-Roy (fast wilting), Boggs (intermediate in wilting), and slow-wilting (SLW) genotypes: NTCPR94-5157 and N049646. Soybean seeds were germinated in flat trays in vermiculite. Uniform size seedlings at about the V1 stage (fully developed unifoliate leaves and one unrolled trifoliate leaf) were transplanted into $9.45 \mathrm{~L}$ pots filled with field soil. Soil characteristics were silty loam with $\mathrm{pH} 6.3,1.1 \%$ organic matter, a cation exchange capacity of $15 \mathrm{cmol} / \mathrm{kg}$, and soil textural fractions of $26 \%$ sand, $56 \%$ silt, and $18 \%$ clay. The soil contained an abundant native population of B. japonicum. Soil in pots, weighed, saturated with deionized water, and drained. The pots were then weighed to obtain the water field capacity using Watermark 200SS soil sensors inserted in the pots and read daily with a Soil Moisture Meter (Irrometer Company, Inc., Riverside, California, USA). Well watered plants were kept between -15 and $-20 \mathrm{kPa}$ (this was considered field capacity for the control plants), and drought stressed plants were kept between -90 and $-100 \mathrm{kPa}$ (Bellaloui et al., 2010a). Plants were considered fully matured when they reached R8 (full maturity) according to Fehr and Caviness (1977). At full maturity, $95 \%$ of pods reached full maturity). Three replicates were used in each treatment, and experiment was repeated. Therefore, the total replicates used in this experiment is 6. Each pot had three plants. Greenhouse temperature conditions were maintained at $34 \pm 9^{\circ} \mathrm{C}$ during the day and $28 \pm 7^{\circ} \mathrm{C}$ at night. Photosynthetic photon flux density (PPFD) during the day of about $800-2300 \mu \mathrm{mol} \cdot \mathrm{m}^{-2} \cdot \mathrm{s}^{-1}$ was measured by a Quantum Meter (Spectrum Technologies, Inc., Aurora. Illinois, USA). The wide range of light intensity reflects a bright, sunny, or cloudy day. The two experiments were conducted simultaneously in two different bays during the normal growing season (from April to September) to simulate the growing season photoperiod of soybean production in the midsouth USA. The fully expanded leaves at seed-fill stages (R5-R6) were analyzed for NF, NA, and mineral nutrition. Seed fill stage was chosen as it is considered as the most critical stage for soybean for seed evaluation, and any impact on nutrients uptake or movement from leaves to seed will impact seed quality. Mature seeds at R8 were harvested and analyzed for seed protein, oil, fatty acids, sugars, and minerals. In a separate preliminary experiment to further investigate the role of $\mathrm{K}$ and $\mathrm{B}$ (among the responsive nutrients to SLW trait under drought), a foliar $\mathrm{K}$ application at a rate of $1.75 \% \mathrm{~K}_{2} \mathrm{SO}_{4}$ and foliar B application at a rate of $1.1 \mathrm{~kg} \mathrm{ha}^{-1} \mathrm{H}_{3} \mathrm{BO}_{3}$ were made at seed-fill stages (R5-R6). Leaves were collected for $\mathrm{K}$ and $\mathrm{B}$ analysis 2 weeks after $\mathrm{K}$ and $\mathrm{B}$ application. Foliar $\mathrm{K}$ and $\mathrm{B}$ were applied only to SLW genotypes under moderate drought stress $(-99$ to $-100 \mathrm{kPa})$ and severe drought stress ( 


\section{MINERALS, N, AND S ANALYSES IN LEAVES AND SEEDS}

The fully expanded youngest leaves at seed-fill stage (R5-R6) were collected from each treatment and replicate and were analyzed for macro- and micronutrients. Mature seeds at R8 were collected and analyzed for seed minerals, and $\mathrm{N}$ and $\mathrm{S}$ concentrations. Leaf and seed samples were ground to pass through a 1-mm sieve using a Laboratory Mill 3600 (Perten, Springfield, IL). Leaf and seed macro- and micro-nutrients were analyzed by digesting $0.5 \mathrm{~g}$ of dried ground seed in $\mathrm{HNO}_{3}$ in a microwave digestion system. The concentrations of nutrients were determined using inductively coupled plasma spectrometry (ICP) (Bellaloui et al., 2011, 2013). Nitrogen and S were measured in a 0.25 -g sample using a LECO CNS-2000 elemental analyzer (LECO Corporation, St. Joseph, MI, USA) (Bellaloui et al., 2011). Concentrations of B, Fe, and $\mathrm{P}$ were determined as indicated in the following sections.

\section{BORON MEASUREMENT}

Boron concentration was determined in fully expanded leaves at seed-fill stages (R5-R6) using the Azomethine-H method (Lohse, 1982; Dordas, 2006; Dordas et al., 2007). Briefly, a 1.0-g seed sample was ashed at $500^{\circ} \mathrm{C}$ and then extracted with $20 \mathrm{ml}$ of $2 \mathrm{M} \mathrm{HCl}$ at $90^{\circ} \mathrm{C}$ for $10 \mathrm{~min}$ and filtered. The filtered mixture was transferred to plastic vials, and a 2-ml sample of the solution was added to $4 \mathrm{ml}$ of buffer solution (containing 25\% ammonium acetate, $1.5 \%$ EDTA, and $12.5 \%$ acetic acid) and $4 \mathrm{ml}$ of freshly prepared azomethine- $\mathrm{H}$ solution $(0.45 \%$ azomethine- $\mathrm{H}$ and $1 \%$ of ascorbic acid) (John et al., 1975). The concentration of boron in leaves and seeds was determined in the samples after color development at $420 \mathrm{~nm}$ using a Beckman Coulter DU 800 spectrophotometer (Beckman Coulter, Inc., Brea, CA, USA).

\section{IRON MEASUREMENT}

Iron concentration in leaves and seed was measured after acid wet digestion, extraction, and reaction of the reduced ferrous Fe with 1,10-phenanthroline according to the methods of Bandemer and Schaible (1944) and Loeppert and Inskeep (1996). A sample of $2 \mathrm{~g}$ of dried ground seed was acid digested (Analytical Methods Committee, 1959). Then, the acids were removed by volatilization, and the soluble constituents were dissolved in $2 \mathrm{M}$ of $\mathrm{HCl}$. Standard solutions of $\mathrm{Fe}$ ions were prepared in $0.4 \mathrm{M} \mathrm{HCl}$, and ranged from 0.0 to $4 \mu \mathrm{g} \mathrm{mL}^{-1}$ of $\mathrm{Fe}$. A phenanthroline solution of $0.25 \%(\mathrm{w} / \mathrm{v})$ was prepared in $25 \%(\mathrm{v} / \mathrm{v})$ ethanol. The quinol solution $(1 \% \mathrm{w} / \mathrm{v})$ reagent was prepared on the day of use. About $4 \mathrm{~mL}$ of the sample solution was added to a $25-\mathrm{mL}$ volumetric flask. The aliquot was diluted to $5 \mathrm{~mL}$ using $0.4 \mathrm{M} \mathrm{HCl}$. Quinol solution $(1 \mathrm{~mL})$ was added and mixed, and then $3 \mathrm{~mL}$ of the phenanthroline solution and $5 \mathrm{~mL}$ of the tri-sodium citrate solution $(8 \% \mathrm{w} / \mathrm{v})$ were added. The solution was diluted to $25 \mathrm{~mL}$ with distilled water and incubated at room temperature for $4 \mathrm{~h}$. The concentrations of Fe in samples were read at $510 \mathrm{~nm}$ using the Beckman Coulter DU 800 spectrophotometer.

\section{PHOSPHORUS MEASUREMENT}

Concentration of $\mathrm{P}$ was measured in leaves at seed-fill stages (R5R6) and in seeds at maturity (R8). Phosphorus measurement was carried out spectrophotometrically as the yellow phosphorvanado-molybdate complex according to Cavell (1955). A dried ground leaf and seed sample of $2 \mathrm{~g}$ was ashed to completely destroy organic matter. After ashing, $10 \mathrm{~mL}$ of $6 \mathrm{M} \mathrm{HCl}$ was added. The sample was placed in a water bath to evaporate the solution to dryness, and then kept under heat and $2 \mathrm{~mL}$ of $36 \%$ $\mathrm{v} / \mathrm{v} \mathrm{HCl}$ was added and the sample was boiled. A volume of $10 \mathrm{~mL}$ distilled water was added, and the solution was then boiled for a few seconds, transferred to a $50-\mathrm{mL}$ volumetric flask, diluted to $50 \mathrm{~mL}$ with distilled water, and filtered. A volume of $5 \mathrm{~mL}$ of $5 \mathrm{M} \mathrm{HCl}$ and $5 \mathrm{~mL}$ of ammonium molybdate-ammonium metavanadate reagent was added to $5 \mathrm{~mL}$ of the filtrate. The solution was diluted with distilled water to $50 \mathrm{~mL}$ and allowed to stand for $30 \mathrm{~min}$. Ammonium molybdate-ammonium metavanadate was made by dissolving $25 \mathrm{~g}$ of ammonium molybdate and $1.25 \mathrm{~g}$ of ammonium metavanadate in $500 \mathrm{~mL}$ of distilled water. Phosphorus concentration was measured after color development using the Beckman Coulter DU 800 spectrophotometer at $400 \mathrm{~nm}$. Standards of $\mathrm{P}$ solutions with concentrations ranging from $0-50 \mu \mathrm{g} \mathrm{mL}^{-1}$ of $\mathrm{P}$ ) were prepared using dihydrogen orthophosphates.

\section{SEED ANALYSIS FOR PROTEIN, OIL, AND FATTY ACIDS}

Mature seeds were collected from each treatment and replicate and analyzed for protein, oil, and fatty acids. A sample of $25 \mathrm{~g}$ of seed was ground using the Laboratory Mill 3600. Analyses were conducted by near infrared reflectance (NIR) (Wilcox and Shibles, 2001; Bellaloui et al., 2009) using a diode array feed analyzer AD 7200 (Perten, Springfield, IL, USA). The initial calibrations were developed by the University of Minnesota using Perten's Thermo Galactic Grams PLS IQ software. The calibration curve was established according to AOAC methods (AOAC, $1990 a, b)$. Analyses of protein and oil were performed based on a seed dry matter basis (Wilcox and Shibles, 2001; Boydak et al., 2002), and fatty acids were analyzed on an oil basis.

\section{SEED ANALYSIS FOR SUCROSE, RAFFINOSE, AND STACHYOSE}

Seed at harvest maturity were collected and analyzed for sucrose, raffinose, and stachyose concentrations. A sample of $25 \mathrm{~g}$ of seed from each plot was ground using the Laboratory Mill 3600. Analyses were conducted by NIR (Wilcox and Shibles, 2001; Bellaloui et al., 2010b) using the AD 7200 array feed analyzer. Analyses of sugars were performed based on a seed dry matter basis (Wilcox and Shibles, 2001; Boydak et al., 2002).

\section{SEED GLUCOSE DETERMINATION}

Concentration in mature seeds was determined according to an enzymatic reaction using a Glucose (HK) Assay Kit, Product Code GAHK-20 (Sigma-Aldrich Co, St Louis, MO, USA). Glucose during this reaction is phosphorylated by adenosine triphosphate (ATP) in a reaction catalyzed by hexokinase. The glucose-6-phosphate (G6P) produced is then oxidized to 6-phosphogluconate by oxidized nicotinamide adenine dinucleotide (NAD) in a reaction catalyzed by glucose-6-phosphate dehydrogenase (G6PDH). An equimolar amount of NAD is then reduced to $\mathrm{NADH}$, and the increase in absorbance at $340 \mathrm{~nm}$ is directly proportional to glucose concentration in the sample. The Glucose (HK) Assay Reagent was reconstituted according to the manufacturers' instructions in $20 \mathrm{ml}$ deionized water. 
Seed samples were ground using the Laboratory Mill 3600 to obtain uniform particles. A random ground sample of $0.1 \mathrm{mg}$ was extracted with deionized water. Then, the sample solution was heated by heat plate to aid extraction. The extract was diluted to 1:100 with deionized water to obtain a range of 0.05 to $5 \mathrm{mg}$ glucose $\mathrm{ml}^{-1}$. A $100 \mu \mathrm{l}$ sample was added to $1 \mathrm{ml}$ of the Glucose (HK) Assay Reagent and incubated at room temperature for $15 \mathrm{~min}$. A sample blank consisting of $100 \mu \mathrm{l}$ of sample and $1 \mathrm{ml}$ of deionized water, and a reagent blank consisting of $1 \mathrm{ml}$ of Glucose $(\mathrm{HK})$ Assay Reagent and $100 \mu l$ of deionized water were also prepared. The absorbance was read at $340 \mathrm{~nm}$ using the Beckman Coulter DU 800 spectrophotometer. The concentration of the glucose was expressed as $\mathrm{mg} \mathrm{g}^{-1} \mathrm{dwt}$.

\section{SEED FRUCTOSE DETERMINATION}

The concentration of fructose in seed was determined enzymatically using a Fructose Assay Kit, Product Code FA-20 (SigmaAldrich Co., St. Louis, MO, USA). Fructose in this reaction is phosphorylated by ATP in a reaction catalyzed by hexokinase. Fructose 6-phosphate is converted to G6P by phosphoglucose isomerase (PGI). Then, oxidation of G6P to 6-phosphogluconate occurred in the presence of NAD in the reaction catalyzed by glucose-6-phosphate dehydrogenase (G6PDH). An equimolar amount of NAD is then reduced to $\mathrm{NADH}$, and the increase in absorbance at $340 \mathrm{~nm}$ is directly proportional to fructose concentration in a sample. Seed samples were ground using the Laboratory Mill 3600 as described above. A random sample of $0.1 \mathrm{mg}$ was extracted with deionized water. The sample solution was heated by heat plate to aid extraction and diluted to 1:100 with deionized water to obtain a range of 100-1000 $\mu \mathrm{g}$ fructose $\mathrm{ml}^{-1}$. A sample of $100 \mu \mathrm{l}$ was added to $2 \mathrm{ml}$ of the Glucose Assay Reagent and $0.02 \mathrm{ml}$ PGI and incubated at room temperature for $15 \mathrm{~min}$. A sample blank consisting of $100 \mu \mathrm{l}$ of sample and $0.02 \mathrm{ml}$ deionized water was prepared, and a sample of Glucose Assay Reagent blank and PGI blank was also prepared as recommended by the manufacturer. Samples were read after $15 \mathrm{~min}$ at absorbance $340 \mathrm{~nm}$ using the Beckman Coulter DU $800 \mathrm{spec}-$ trophotometer. The concentration of seed fructose was expressed as $\mathrm{mg} \mathrm{g} \mathrm{dwt}^{-1}$.

\section{in vivo NITRATE REDUCTASE ASSAY}

Nitrate reductase activity (NRA) was measured in fully expanded leaves and placed in the buffer solution for in vivo NRA assay based on the method of Klepper and Hageman (1969). Briefly, approximately $0.3 \mathrm{~g}$ of tissue was placed in $10 \mathrm{~mL}$ of potassium

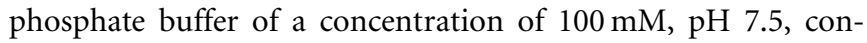
taining $1 \%(\mathrm{v} / \mathrm{v}) 1$-propanol, in a flask. The buffer solution with samples was vacuum filtered for $1 \mathrm{~min}$, and then flashed with nitrogen gas for $30 \mathrm{~s}$ and then incubated at $30^{\circ} \mathrm{C}$. A sample of $0.5 \mathrm{~mL}$ was taken from each replicate at regular intervals $(0,60$, 120,180 , and $300 \mathrm{~min}$ ) for nitrite determination. Samples were extracted with $5 \mathrm{~mL}$ of deionized water and reacted with $1.0 \mathrm{~mL}$ of $1 \%(\mathrm{w} / \mathrm{v})$ sulfanilamide in $10 \% \mathrm{v} / \mathrm{v} \mathrm{HCl}$ and $1.0 \mathrm{~mL}$ of $\mathrm{N}$ naphthyl-(1)-ethylenediamine dihydrochloride (0.1\%). The samples were read after $30 \mathrm{~min}$ at $540 \mathrm{~nm}$ using a Beckman Coulter DU 800 spectrophotometer. The concentration of nitrite sing $\mathrm{KNO}_{2}$ was calculated from a standard calibration curve. Potential
NRA (PNRA) under conditions where nitrate is limited was determined by adding exogenous nitrate to the incubation solution at a concentration of $10 \mathrm{mM}$ of $\mathrm{KNO}_{3}$. NRA was expressed as $\mathrm{NO}_{2}$ $\mathrm{g} \mathrm{fwt}^{-1} \mathrm{~h}^{-1}$

\section{ACETYLENE REDUCTION ASSAY}

Nitrogenase activity (nitrogen fixation, NF) at seed-fill stages (R5-R6) was assayed using the acetylene reduction assay (Hardy et al., 1968; Zablotowicz et al., 1981; Bellaloui and Mengistu, 2008). Roots with nodules intact were excised and incubated in $1 \mathrm{~L}$ Mason jars. Three roots were placed in the Mason jars and sealed. A $10 \%$ volume of air was removed and replaced with an equal volume of acetylene. Duplicate $1.0 \mathrm{ml}$ gas samples were removed after $1 \mathrm{~h}$ of incubation at room temperature and analyzed by gas chromatography (An Agilent HP6960, Agilent Technologies, Wilmington, DE) for ethylene formation. The gas chromatography instrument was equipped with manual injector, injector loop, sample splitter, flame ionization detector (FID), and thermal conductivity detector (TCD). A $0.25 \mathrm{ml}$ sample of gas was directed into a $30 \mathrm{~m}$ length $\times 0.53 \mathrm{~mm}$ i.d. alumina megabore column, connected to the FID, and $0.25 \mathrm{ml}$ of sample was injected into a HP- PLOT D column $(30 \mathrm{~m}$ length $\times 0.53 \mathrm{~mm}$ i.d. megabore with $40 \mu \mathrm{m}$ film; helium was used as a carrier gas. Chem Station software was used to conduct the integration of chromatographs.

\section{LEAF WATER POTENTIAL MEASUREMENT}

In a non-repeated experiment with three replicates, leaf water potential (LWP, $\Psi_{\mathrm{w}}$ ) was determined on young and fully expanded leaves at vegetative stage using leaf cutter thermocouple psychrometers (J.R.D. Merrill Specialty Equipment, Logan, UT, USA) at mid-day (1200-1300 h). A 5-mm diameter leaf disc was taken and placed in a leaf cutter thermocouple psychrometer. Measurements were conducted on three individual plants (replicate) of each genotype in each water treatment (well-watered and drought stress). The leaf cutter thermocouple psychrometers were placed in a water bath at $25^{\circ} \mathrm{C}$ for $4 \mathrm{~h}$. Outputs from the psychrometers were recorded by a PSYPRO data logger (WESCOR, Inc., Logan, UT, USA).

\section{EXPERIMENTAL DESIGN AND STATISTICAL ANALYSIS}

The experimental design was a randomized complete block design with a split-split plot arrangement of treatments; with watering as a main plot, trait as sub-plot, and genotype as subsub-plot. Analysis of variance using Proc Mixed was conducted using a split plot model in SAS (SAS Institute, 2001). Means were separated by Fisher's least significant difference test at the 5\% probability level.

\section{RESULTS}

\section{ANALYSIS OF VARIANCE}

Analysis of variance showed that slow-wilting (Trait), watering treatment (Treat), and their interactions were the main sources of variability for mineral nutrients in leaves. The Trait, Treat and Trait $\times$ Treat interaction were significant at $P \leq 0.001$ for minerals $\mathrm{Ca}, \mathrm{K}, \mathrm{P}, \mathrm{B}, \mathrm{Cu}, \mathrm{Fe}$, and $\mathrm{Na}$. Trait and Trait $\times$ Treat were not significant for $\mathrm{S}$ and $\mathrm{Mn}$, and Trait $\times$ Treat was not significant for Zn (Table 1). The interaction between Trait and Treat 
indicated that the responses of these leaf minerals to watering regime (well-watered or drought stressed) were influenced by slow-wilting. The trend was similar for seed protein, oil, fatty acids, and sugars (Table 2), with Trait, Treat, and Trait $\times$ Treat interaction being significant for all parameters measured, except Treat was not significant for stearic acid and glucose, Trait was not significant for palmitic acid and Trait $\times$ Treat interaction was not significant for linolenic aicd and glucose. This indicates that alteration in seed composition constituents was different among the treatment and trait combinations. For seed minerals, all seed minerals were significantly affected by watering treatment (Table 3). Trait was significantly different for $\mathrm{P}$ and $\mathrm{B}$, and the interaction between the Trait and watering treatment was significant only for seed $\mathrm{Ca}$ and $\mathrm{K}$. When Trait was replaced by genotype in the model to analyze genotype effects, the results were similar to the analysis of Trait for leaf and seed composition components (data not shown). Since the Trait, Treat, and their interactions were the main significant sources of variability, and the trend of variables was generally similar in both experiments, the results were pooled and combined making the total number of replicates 6 .

\section{RESPONSE OF LEAF NUTRIENTS TO SLOW-WILTING TRAIT}

Under well-watered conditions, genotypes accumulated different concentrations of leaf minerals, (Table 4). The accumulation level of each mineral in leaves depended on the mineral and genotype, but there were trends. Three nutrients that significantly accumulated at higher levels in SLW genotypes were N, B, and Zn (Table 4). Also, Ca, K, Mg, Fe tended to be lower in the SLW lines as compared to checks. Under water stress, however, all leaf minerals, except $\mathrm{Mg}$, S, and Mn had higher concentrations in leaves of SLW genotypes, and the concentration increase between certain SLW genotypes and certain check genotypes reached more than $50 \%$ in $\mathrm{P}, \mathrm{Cu}, \mathrm{Fe}$, and $\mathrm{Na}$. The concentrations of $\mathrm{Ca}, \mathrm{K}, \mathrm{N}$, and $\mathrm{B}$

Table 3 | Analysis of variance for responses of seed minerals and $\mathbf{N}$ to slow-wilting phenotype (Trait) under well-watered and drought stressed conditions (Treat) in soybean genotypes differing in slowwilting trait.

\begin{tabular}{|c|c|c|c|c|c|c|}
\hline $\begin{array}{l}\text { Source of } \\
\text { variability }\end{array}$ & $\begin{array}{l}\text { Seed Ca } \\
(\%)\end{array}$ & $\begin{array}{l}\text { Seed K } \\
(\%)\end{array}$ & $\begin{array}{l}\text { Seed N } \\
(\%)\end{array}$ & $\begin{array}{l}\text { Seed P } \\
(\%)\end{array}$ & $\begin{array}{l}\text { Seed B } \\
\left(\mathrm{mg} \mathrm{kg}^{-1}\right)\end{array}$ & $\begin{array}{l}\text { Seed Fe } \\
\left(\mathrm{mg} \mathrm{kg}^{-1}\right)\end{array}$ \\
\hline Exp & NS & NS & NS & NS & NS & NS \\
\hline Trait & NS & NS & NS & $*$ & $* * *$ & NS \\
\hline Exp $\times$ Trait & NS & NS & NS & NS & NS & NS \\
\hline $\begin{array}{l}\text { Treatment } \\
\text { (Treat) }\end{array}$ & $* * *$ & $* * *$ & $* * *$ & $* * *$ & $* * *$ & $* * *$ \\
\hline Exp $\times$ Treat & NS & NS & NS & NS & NS & NS \\
\hline Trait $\times$ Treat & $* * *$ & $* * *$ & NS & NS & $*$ & NS \\
\hline $\begin{array}{l}\text { Exp } \times \text { Trait } \\
\times \text { Treat }\end{array}$ & NS & * & NS & NS & NS & NS \\
\hline
\end{tabular}

${ }^{*} P \leq 0.05 ;{ }^{*} P \leq 0.01 ;{ }^{* *} p \leq 0.001$. The experiment was repeated twice and number of replicates was six.

Table 1 | Analysis of variance for responses of leaf minerals, $\mathrm{N}, \mathrm{S}$, nitrogen fixation (ARA, $\mu \mathrm{mol}_{\text {of }} \mathrm{C}_{2} \mathrm{H}_{4} \mathrm{plant}^{-1} \mathrm{~h}^{-1}$ ), rate of leaf nitrate assimilation (NRA, $\mu \mathrm{mol} \mathrm{NO} \mathrm{g} \mathrm{fwt}^{-1} \mathrm{~h}^{-1}$ ), and nodule NRA ( $\mu \mathrm{mol} \mathrm{NO}_{2} \mathrm{~g} \mathrm{fwt}^{-1} \mathrm{~h}^{-1}$ ) to slow-wilting phenotype (Trait) under well-watered and drought stressed conditions (Treat) in soybean genotypes differing in slow-wilting trait.

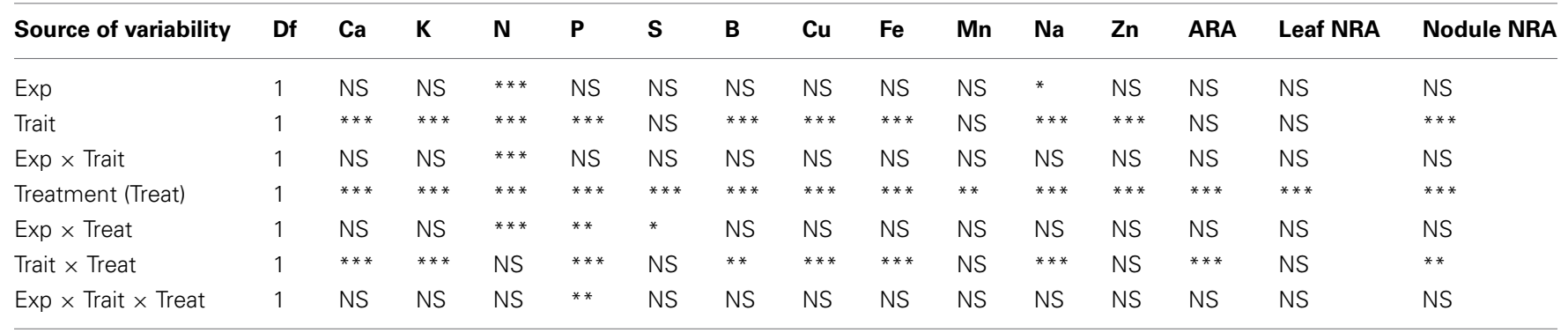

${ }^{*} P \leq 0.05 ;{ }^{* *} P \leq 0.01 ;{ }^{* * *} p \leq 0.001$. The experiment was repeated twice and number of replicates was six.

Table 2 | Analysis of variance for responses of seed composition (protein, oil, fatty acids, and sugars) percentage (\%) to slow-wilting phenotype (Trait) under well-watered and drought stressed conditions (Treat) in soybean genotypes differing in slow-wilting trait.

\begin{tabular}{|c|c|c|c|c|c|c|c|c|c|c|c|c|}
\hline Source of variability & Protein & Oil & C16:0 & C18:0 & C18:1 & C18:2 & C18:3 & Sucrose & Raffinose & Stachyose & Glucose & Fructose \\
\hline Exp & NS & NS & NS & NS & NS & NS & $* *$ & NS & NS & NS & NS & $*$ \\
\hline Trait & $* * *$ & $* * *$ & $* * *$ & NS & $* * *$ & $* * *$ & $* * *$ & $* * *$ & $* *$ & $* * *$ & $*$ & NS \\
\hline Exp $\times$ Trait & NS & NS & NS & $* * *$ & NS & NS & NS & NS & NS & NS & NS & NS \\
\hline Treatment (Treat) & $* * *$ & $* * *$ & NS & $* * *$ & $* * *$ & $* * *$ & $* * *$ & $* * *$ & $* *$ & $* * *$ & NS & $* * *$ \\
\hline Exp $\times$ Treat & NS & NS & NS & $* * *$ & $* *$ & $* * *$ & NS & NS & NS & NS & NS & NS \\
\hline Trait $\times$ Treat & $* * *$ & $* * *$ & $* * *$ & $* *$ & $* * *$ & $* * *$ & NS & $* *$ & $* *$ & $* * *$ & NS & $* * *$ \\
\hline Exp $\times$ Trait $\times$ Treat & NS & NS & NS & $* * *$ & NS & NS & NS & NS & NS & NS & NS & NS \\
\hline
\end{tabular}

${ }^{*} P \leq 0.05 ;{ }^{*} P \leq 0.01 ;{ }^{* *} p \leq 0.001$. The experiment was repeated twice and number of replicates was six. 
were also significantly higher in SLW genotypes than the checks, but no clear trends for S, Mn, or Zn concentrations in leaves were observed.

\section{RESPONSE OF SEED NUTRIENTS TO SLOW-WILTING TRAIT}

Under well-watered conditions, seed protein was significantly higher in checks than in SLW genotypes, but oil was the opposite (lower), which is consistent with the established inverse relationship between protein and oil (Table 5). Oleic acid level was higher in SLW genotypes than in checks. Both linoleic and linolenic acids were higher in checks than in SLW genotypes. Since the check and SLW genotypes do not have identical genetic background, the differences in protein, oil, and fatty acid levels between checks and SLW genotypes could be due to either the SLW trait, other genotypic differences or both. The range in values for protein, oil, and fatty acids in all genotypes was within the range of normal soybean genotypes. Seed sucrose and stachyose levels were higher in SLW genotypes, and fructose was higher in check genotypes. There was no clear trend in seed raffinose and glucose (Table 4). Under drought stress, seed protein, oleic acid, and sugars were higher in SLW genotypes than checks (Table 5). The most interesting observation was that seed oil was higher in the SLW than the checks under well-watered and drought conditions. Whereas, the protein level went up under dry conditions for both normal and SLW (Table 5). However, linoleic and linolenic acid levels were lower in SLW genotypes. No clear trend for palmitic and stearic acids was evident (Table 5). Under well-watered conditions, $\mathrm{Ca}$ and $\mathrm{K}$ concentrations in seeds were higher in the checks genotypes than in SLW genotypes, and B concentration was higher in SLW genotypes than in the checks genotypes (Table 6). There were no clear trends for the rest of the nutrients recorded. Under drought stress, Ca, K, and B were

Table 4 | Responses of leaf minerals, N, and S to slow-wilting (SLW) (drought tolerance) phenotype (Trait) in soybean genotypes differing in slow-wilting trait under well-watered (W) and drought stressed (DS) conditions*.

\begin{tabular}{|c|c|c|c|c|c|c|c|c|c|c|c|c|c|}
\hline Genotype & Trait & $\begin{array}{l}\mathrm{Ca} \\
(\%)\end{array}$ & $\begin{array}{l}K \\
(\%)\end{array}$ & $\begin{array}{l}\mathbf{M g} \\
(\%)\end{array}$ & $\begin{array}{l}N \\
(\%)\end{array}$ & $\begin{array}{l}P \\
(\%)\end{array}$ & $\begin{array}{l}\text { S } \\
(\%)\end{array}$ & $\begin{array}{l}\text { B } \\
\left(\mathrm{mg} \mathrm{kg}^{-1}\right)\end{array}$ & $\begin{array}{l}\mathrm{Cu} \\
\left(\mathrm{mg} \mathrm{kg}^{-1}\right)\end{array}$ & $\begin{array}{l}\mathrm{Fe} \\
\left(\mathrm{mg} \mathrm{kg}^{-1}\right)\end{array}$ & $\begin{array}{l}\text { Mn } \\
\left(\mathrm{mg} \mathrm{kg}^{-1}\right)\end{array}$ & $\begin{array}{l}\mathrm{Na} \\
\left(\mathrm{mg} \mathrm{kg}^{-1}\right)\end{array}$ & $\begin{array}{l}\mathrm{Zn} \\
\left(\mathrm{mg} \mathrm{kg}^{-1}\right)\end{array}$ \\
\hline \multicolumn{14}{|l|}{$\mathbf{W}$} \\
\hline BOGGS & Check & 1.25 & 2.69 & 0.63 & 4.53 & 0.35 & 0.24 & 64.5 & 4.75 & 107 & 112 & 23.0 & 79.7 \\
\hline NC-Roy & Check & 1.29 & 3.10 & 0.63 & 4.42 & 0.45 & 0.26 & 77.8 & 4.32 & 107 & 83.6 & 25.5 & 65.8 \\
\hline NO49646 & SLW & 1.08 & 2.19 & 0.57 & 5.16 & 0.44 & 0.27 & 82.1 & 4.42 & 103 & 107 & 25.4 & 81.0 \\
\hline NTCPR945 & SLW & 1.13 & 2.13 & 0.60 & 5.40 & 0.38 & 0.26 & 91.5 & 4.59 & 94.4 & 88.3 & 20.0 & 90.7 \\
\hline LSD & & 0.02 & 0.09 & 0.01 & 0.15 & 0.01 & 0.004 & 4.28 & 0.25 & 2.16 & 2.87 & 1.28 & 2.11 \\
\hline \multicolumn{14}{|l|}{ DS } \\
\hline BOGGS & Check & 1.05 & 2.30 & 0.70 & 4.18 & 0.33 & 0.26 & 116 & 4.63 & 87.9 & 127 & 31.0 & 92.8 \\
\hline NC-Roy & Check & 1.13 & 2.42 & 0.69 & 4.06 & 0.34 & 0.31 & 114 & 5.67 & 84.5 & 102 & 39.6 & 92.0 \\
\hline NO49646 & SLW & 1.42 & 2.68 & 0.71 & 4.84 & 0.65 & 0.29 & 140 & 7.08 & 138 & 121 & 60.7 & 93.7 \\
\hline NTCPR945 & SLW & 1.54 & 2.82 & 0.70 & 4.97 & 0.64 & 0.28 & 161 & 7.86 & 127 & 92.1 & 73.8 & 105 \\
\hline LSD & & 0.035 & 0.05 & 0.02 & 0.26 & 0.038 & 0.016 & 5.76 & 0.42 & 3.78 & 5.08 & 3.12 & 3.27 \\
\hline
\end{tabular}

*The experiment was repeated twice and values are means of six replicates.

Table 5 | Responses of seed composition (protein, oil, fatty acids, and sugars) (\%) to slow-wilting in soybean genotypes differing in slow-wilting (SLW) trait under well-watered (W) and drought stressed (DS) conditions*.

\begin{tabular}{|c|c|c|c|c|c|c|c|c|c|c|c|c|c|}
\hline Genotype & Trait & Protein & Oil & C16:0 & C18:0 & C18:1 & C18:2 & C18:3 & Sucrose & Raffinose & Stachyose & Glucose & Fructose \\
\hline \multicolumn{14}{|l|}{$\mathbf{W}$} \\
\hline BOGGS & Check & 42.2 & 19.5 & 10.5 & 3.7 & 20.2 & 58.5 & 7.5 & 3.5 & 0.47 & 3.3 & 2.1 & 0.94 \\
\hline NC-Roy & Check & 41.0 & 20.1 & 11.1 & 3.6 & 20.0 & 58.3 & 6.9 & 3.6 & 0.55 & 3.3 & 1.7 & 0.90 \\
\hline NO49646 & SLW & 40.6 & 20.8 & 11.7 & 3.4 & 22.2 & 56.3 & 6.5 & 4.3 & 0.52 & 3.6 & 2.2 & 0.86 \\
\hline NTCPR945 & SLW & 40.0 & 21.6 & 11.7 & 3.3 & 22.8 & 56.3 & 6.3 & 3.9 & 0.52 & 3.9 & 1.6 & 0.70 \\
\hline LSD & & 0.324 & 0.18 & 0.23 & 0.081 & 0.47 & 0.45 & 0.23 & 0.17 & 0.025 & 0.14 & 0.19 & 0.083 \\
\hline \multicolumn{14}{|l|}{ DS } \\
\hline BOGGS & & 43.7 & 18.8 & 10.9 & 3.71 & 25.4 & 53.8 & 6.48 & 2.28 & 0.49 & 4.07 & 1.23 & 0.52 \\
\hline NC-Roy & & 43.7 & 18.6 & 11.4 & 3.72 & 25.4 & 53.7 & 5.88 & 2.25 & 0.54 & 4.85 & 1.56 & 0.51 \\
\hline NO49646 & & 42.7 & 20.6 & 11.9 & 3.72 & 29.7 & 48.1 & 5.97 & 3.20 & 0.60 & 6.62 & 1.93 & 0.69 \\
\hline NTCPR945 & & 42.8 & 20.5 & 11.1 & 3.88 & 33.4 & 45.9 & 5.60 & 4.20 & 0.70 & 6.27 & 1.88 & 0.73 \\
\hline LSD & & 0.35 & 0.33 & 0.27 & 0.20 & 0.50 & 0.42 & 0.16 & 0.15 & 0.027 & 0.35 & 0.18 & 0.026 \\
\hline
\end{tabular}

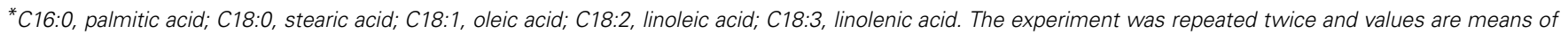
six replicates. 
higher in SLW genotypes than checks (Table 6). There were no clear trends for N, P, or Fe concentrations observed.

\section{NITROGEN FIXATION, ASSIMILATION, AND LEAF WATER POTENTIAL}

Under well-watered conditions, nitrogen fixation was lower in SLW than checks; however, leaf nitrogen assimilation was highest in NO49646 (SLW) and lowest in Boggs (check) Figures 1A,B). Nodule nitrogen assimilation was highest in NTCPR945157 (SLW) and lowest in Boggs (Figure 1C). However there were no consistent differences between the SLW or checks for either leaf or nodule nitrogen assimilation. Under drought stress (Figures 1D-F), both SLW genotypes (NO49646 and NTCPR945157) showed higher nitrogen fixation rates than checks. Comparing the well-watered to the drought stress treatments, ARA in SLW genotypes did not significantly change, but leaf NRA decreased, and nodule NRA was not consistent (Figures 1A-F). Nitrogen assimilation in leaves or nodules did not show any consistent significant differences between the SLW and checks. Leaf water potential (LWP) was not significantly different among genotypes under well-watered conditions or drought stress (Figures 2A,B), may be due to genotypic differences and not the trait. However, when the analysis was done across the two checks and the two SLW genotypes, leaf water potential in the checks was significantly $(P=0.015)$ lower $(-2.00 \mathrm{MPa})$ than in SLW genotypes $(-1.68 \mathrm{MPa})$ under drought stress conditions (Figures 3A,B).

\section{DISCUSSION \\ RESPONSE OF LEAF NUTRIENTS TO SLOW-WILTING TRAIT}

The higher concentrations of $\mathrm{Ca}, \mathrm{K}, \mathrm{Fe}$ in the checks than SLW genotypes could be due to the inherited genotypic differences. A significant crossover interaction is evident for $\mathrm{Ca}, \mathrm{K}, \mathrm{N}, \mathrm{Fe}$ among the two treatments. For these minerals accumulation, the SLW were lower than the checks under well watered conditions, but under drought stress the SLW had higher concentrations than the checks. For P, there was no evident difference between SLW

\begin{abstract}
Table 6 | Responses of seed minerals and $\mathbf{N}$ to slow-wilting in soybean genotypes differing in slow-wilting (SLW) trait under well-watered (W) and drought stressed (DS) conditions*.
\end{abstract}

\begin{tabular}{llllllll}
\hline Genotypes & Trait & $\mathrm{Ca}$ & $\mathrm{K}$ & $\mathrm{N}$ & $\mathrm{P}$ & $\mathrm{B}$ & $\mathrm{Fe}$ \\
& & $(\%)$ & $(\%)$ & $(\%)$ & $(\%)$ & $\left(\mathrm{mg} \mathrm{kg}^{-1}\right)$ & $\left(\mathrm{mg} \mathrm{kg}^{-1}\right)$
\end{tabular}

\begin{tabular}{llllllll}
\hline W & & & & & & & \\
BOGGS & Check & 0.39 & 1.69 & 5.25 & 0.49 & 36.5 & 109 \\
NC-Roy & Check & 0.45 & 1.48 & 5.45 & 0.54 & 44.5 & 96.5 \\
NO49646 & SLW & 0.35 & 1.26 & 4.93 & 0.55 & 60.9 & 89.7 \\
NTCPR945 & SLW & 0.33 & 1.42 & 5.32 & 0.62 & 67.7 & 93 \\
LSD & & 0.019 & 0.043 & 0.216 & 0.026 & 6.24 & 9.82 \\
DS & & & & & & & \\
BOGGS & 0.23 & 1.22 & 3.91 & 0.39 & 31.3 & 61.0 \\
NC-Roy & 0.29 & 1.32 & 4.07 & 0.36 & 34.8 & 59.2 \\
NO49646 & 0.31 & 1.37 & 3.68 & 0.35 & 47.5 & 58.5 \\
NTCPR945 & 0.37 & 1.41 & 4.15 & 0.30 & 45.5 & 53.8 \\
LSD & 0.020 & 0.027 & 0.23 & 0.028 & 2.48 & 2.14 \\
\hline
\end{tabular}

*The experiment was repeated twice and values are means of six replicates. and the checks under well-watered conditions but the magnitude of response to drought stress between the genotypes was not the same. The $\mathrm{P}, \mathrm{Cu}$, and $\mathrm{B}$ concentrations in the SLW lines increased under drought stress more than in the checks. The higher concentrations of $\mathrm{Ca}, \mathrm{K}, \mathrm{P}, \mathrm{B}, \mathrm{Cu}, \mathrm{Fe}$, and $\mathrm{Na}$ in leaves of SLW genotypes compared to the check genotypes under drought stress may indicate the involvement of these nutrients in drought stress response directly or indirectly. Previous research showed that higher accumulation of $\mathrm{K}$ (Bartels and Sunkar, 2005), $\mathrm{Ca}, \mathrm{Cl}$, and $\mathrm{Na}$ in leaves under drought stress (Knight et al., 1997; Schroeder et al., 2001; Furlan et al., 2012) increased osmotic pressure and regulated stomatal opening (Bartels and Sunkar, 2005) in order to maintain cell membrane integrity and function (Wei et al., 2003).

Potassium plays a major role under drought stress because of its involvement in protein synthesis, glycolytic enzymes, photosynthesis, cell expansion, and turgor, carbohydrate movement, stomatal regulation, osmoregulation, energy status, charge balance, homeostasis (Hsiao, 1973; Marschner, 2012), and transpiration (Andersen et al., 1992). Osmotic adjustment using ions such as $\mathrm{K}$ increased drought tolerance because it is more energy efficient for plants to cope with drought using $\mathrm{K}$ than to produce organic solutes (Hsiao, 1973; Hu and Schmidhalter, 2005). For example, Morgan (1992) investigated the genotypic differences in osmoregulation under water stress condition in a glasshouse using sap samples from expanded wheat flag leaves of breeding lines with high and low osmoregulation, and found that high osmoregulation was due to potassium accumulation (78\%) and amino acids (22\%). Ma et al. (2004), working on the accumulation and osmotic adjustment in leaves of Brassica oilseeds under glasshouse conditions, found that the osmotic adjustment in expanded leaves was due to nitrate (42-47\%), soluble sugars (31-38\%), and proline (11-14\%). In expanding leaves, however, the osmotic adjustment was due to $\mathrm{K}$ accumulation (23-27\%), proline (17-22\%), and less due to nitrate and soluble sugars, indicating the complexity of $\mathrm{K}$ dynamics due to its fast mobility in the phloem. Generally, K availability under drought stress decreased due to a decrease in K mobility (Hu and Schmidhalter, 2005), and under these conditions, application of foliar $\mathrm{K}$ was found to decrease the adverse effects of drought (Andersen et al., 1992; Sangakkara et al., 2001). In our experiment and under drought stress, $\mathrm{K}$ level in leaf tissues of SLW genotypes was higher than the check genotypes, and maintaining high level of $\mathrm{K}$ in leaves resulted in higher seed $\mathrm{K}$ in SLW genotypes, suggesting this is a possible mechanism to maintain adequate $\mathrm{K}$ concentration in seeds under drought stress. Under severe drought (soil water potential $=-199 \mathrm{kPa}$ ), however, our preliminary results showed that foliar $\mathrm{K}$ application at a rate of $1.75 \%$ as $\mathrm{K}_{2} \mathrm{SO}_{4}$ to SLW genotypes resulted in an increase of $\mathrm{K}$ in leaves, but very low level of $\mathrm{K}$ in seeds was observed in all genotypes, suggesting the response of $\mathrm{K}$ to slow wilting may depend on the severity of drought.

Phosphorus concentrations in leaves of SLW genotypes were higher than in the check genotypes, suggesting that the SLW genotypes had the ability to maintain higher $\mathrm{P}$ concentrations in leaves under drought stress. Phosphorus is involved in several physiological and biochemical processes such as energy storage and transfer, photosynthesis, and enzyme regulation, and is also integral part of nucleic acids, phospholipids, and phosphoproteins (Hu and Schmidhalter, 2005; Marschner, 2012). It 

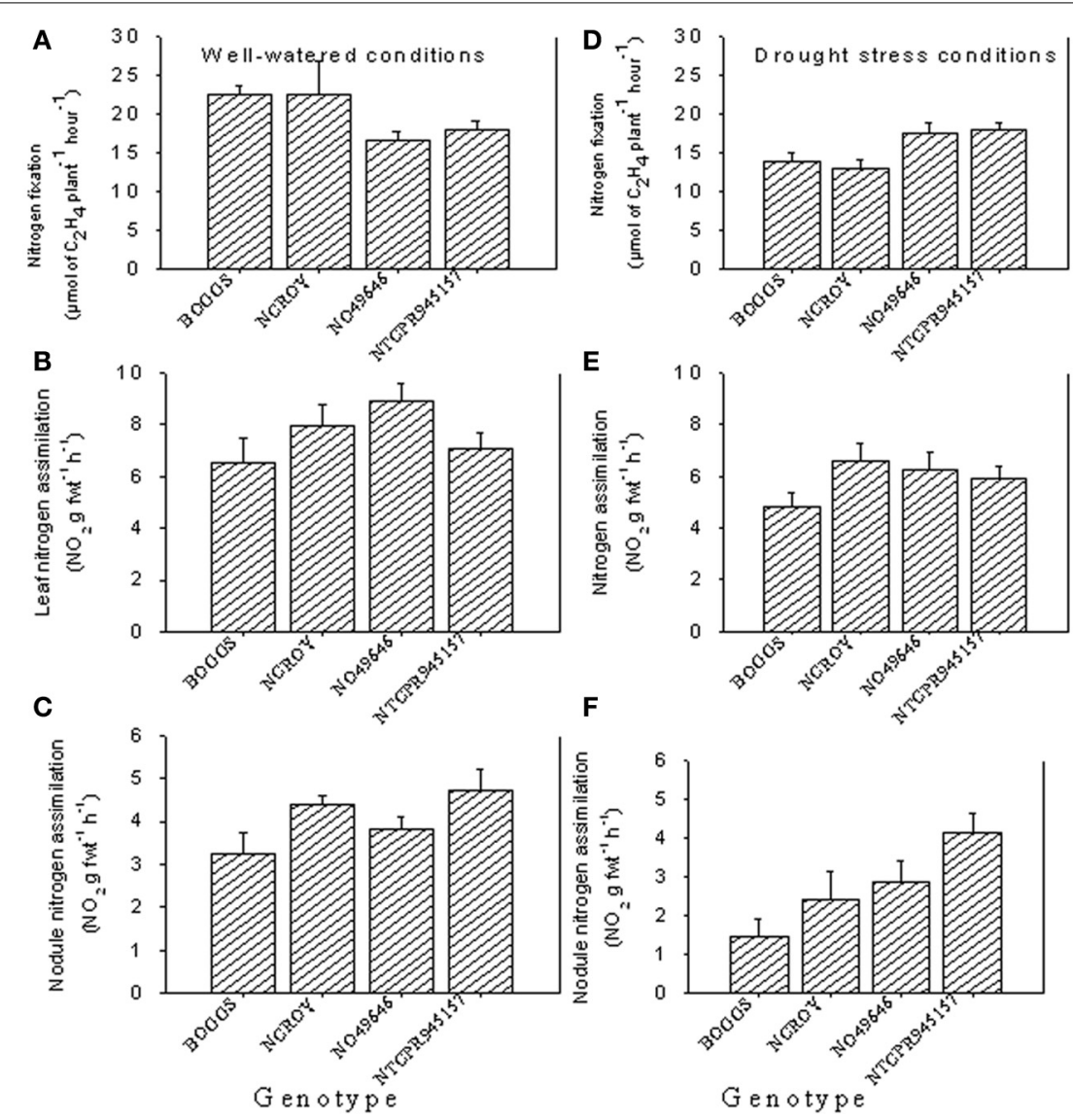

FIGURE 1 | Responses of nitrogen fixation and leaf and nodule nitrogen assimilation under well-watered conditions (A-C) and drought stress conditions (D-F) in soybean genotypes differing in slow-wilting (SLW) phenotype.

was reported that drought stress inhibits $\mathrm{P}$ absorption, uptake, translocation, and accumulation, although the degree of influence of drought on $\mathrm{P}$ is dependent on the severity of drought stress (Rasnick, 1970; Pinkerton and Simpson, 1986). The role of $\mathrm{P}$ under drought stress was attributed to increases in water-use efficiency, stomatal conductance (Brück et al., 2000), photosynthesis (Ackerson, 1985), higher cell membrane stability, and water relations (Sawwan et al., 2000). It was found that P fertilizer application under drought stress can improve plant growth (Ackerson, 1985; Garg et al., 2004; Hu and Schmidhalter, 2005). In our experiment and under drought stress, $\mathrm{P}$ in leaves was higher in SLW genotypes (increase of 94\% in NTCPR94-5157 and 91\% in N04-9646) compared with their equivalent checks Boggs and NC-Roy, respectively), showing a positive response to the SLW trait. This increase in $\mathrm{P}$ in leaves was not reflected in $\mathrm{P}$ in seeds, perhaps due to low mobility and translocation of $\mathrm{P}$ from leaves to seed.

Calcium levels in leaves and seeds were higher in SLW genotypes than in check genotypes, but this response was only shown under drought stress, and not under well-watered conditions where $\mathrm{Ca}$ in leaves and seeds were higher in the check genotypes than in SLW genotypes. Calcium is thought to have a role in drought stress because of its involvement in water and solute movement, stomatal function, and signaling systems under biotic and abiotic stress (McLaughlin and Wimmer, 1999), osmoregulation under drought stress (Knight et al., 1997; Bartels and Sunkar, 2005), and $\mathrm{Ca}^{2+}$-ATPases to restore and maintain homeostasis by pumping $\mathrm{Ca}^{++}$out of the cytosol to terminate a signaling event (Sze et al., 2000). The decrease of Ca in leaves and seeds in the checks may be due to the decrease of Ca uptake and lack of ability of these genotypes to maintain high levels of $\mathrm{Ca}$ in leaves and seeds. Compared with the checks, Ca in SLW genotypes was higher under drought stress (increase of 47\% in NTCPR94-5157 and 26\% in N04-9646 compared with their equivalent checks Boggs and NC-Roy, respectively). The higher increase of $\mathrm{Na}, \mathrm{B}, \mathrm{Fe}$, $\mathrm{Cu}$ in SLW genotypes may indicate possible involvement of these nutrients in stomatal opening and osmoregulation. The little or no response of $\mathrm{Mg}$ and $\mathrm{S}$ could indicate minimal role of these nutrients in drought tolerance and osmoregulation. Although information available on the effect of drought on $\mathrm{S}$ and $\mathrm{Mg}$ nutrition of plants is limited ( $\mathrm{Hu}$ and Schmidhalter, 2005), it was assumed that drought decreases the uptake of $\mathrm{Mg}$ and $\mathrm{S}$ (Scherer, 2001). Hu and Schmidhalter (2005) reported that B deficiency occurs under drought due to low mineralization that dissociates B from organic matter and induces $\mathrm{Mn}, \mathrm{Mo}, \mathrm{Fe}$, and Zn deficiencies. 

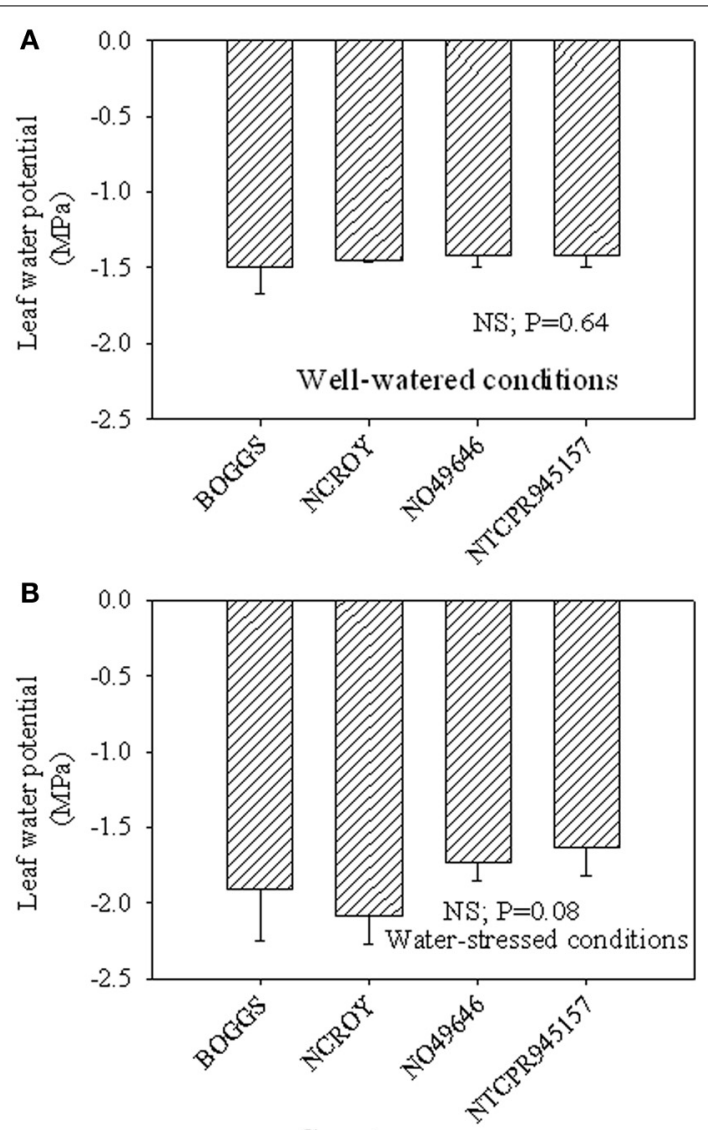

Genotype

FIGURE 2 | Responses of leaf water potential to well-watered conditions (A) and drought stress conditions (B) in soybean genotypes differing in slow-wilting (SLW) phenotype.

\section{RESPONSE OF SEED NUTRIENTS TO SLOW-WILTING TRAIT}

The seed protein, oil, and fatty acid levels in the genotypes were all within normal levels found in soybean lines. The higher seed protein and different fatty acids composition of seed under well-watered conditions in genotypes could be due to genotypic differences. Usually, when soybeans are grown under different conditions, it is observed that when protein percentage increases in a line, the oil percentage will decrease. N049646 was notable in that the oil percentage decreased by only $1 \%$ when protein percentage protein percentage increased by $5 \%$ between wellwatered and drought stress conditions (Table 7). In the other genotypes, protein increased from 3.6 to $7.0 \%$ and oil decreased by 3.6 to $7.5 \%$ (Table 7). Under drought stress, protein and oleic acid increased and linoleic and linolenic acids decreased in all genotypes, but the changes were more extreme in the SLW genotypes for protein and oleic acids. The higher oleic acid in SLW genotypes suggests a possible role of oleic acid as a drought stress indicator. It must be noted that the check genotypes under drought stress conditions also exhibited high protein and oleic acid compared with those grown under well-watered conditions, but the rate of increase was lower than in SLW genotypes.
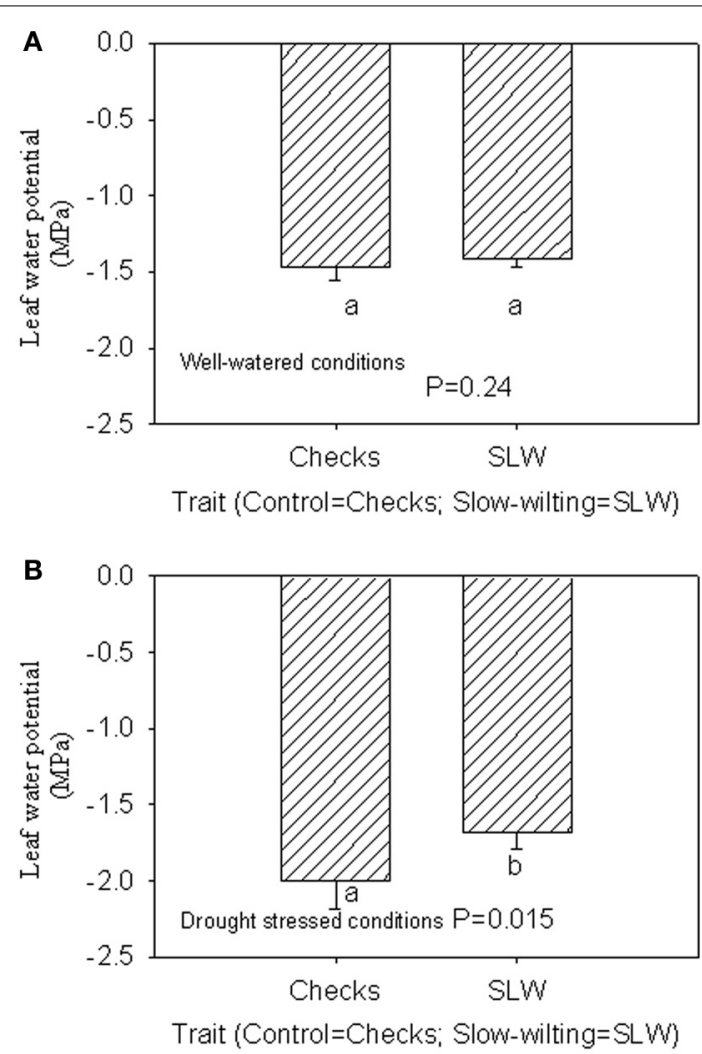

FIGURE 3 | Responses of leaf water potential to well-watered conditions (A) and drought stress conditions (B) across checks and slow-wiling (SLW) soybean genotypes.

A positive response of seed sugars, $\mathrm{Ca}, \mathrm{K}$, and $\mathrm{B}$ to drought stress in SLW genotypes was observed, indicating that sugars, especially sucrose, raffinose, and stachyose may have contributed to drought tolerance and may be considered as drought stress indicator for the SLW trait. In our experiments, the percentage increases in seed sucrose, raffinose, stachyose, glucose, and fructose in NTCPR945 under drought stress were 7.7, 34.6, 60.8, 17.5, $4.3 \%$, respectively, although the percentages increase in NO49646 were less than in NTCPR946 (Table 7)The biological function of raffinose and stachyose are not well understood (Ren et al., 2009), although the oligosaccharides (sucrose, raffinose, and stachyose) involvement in seed quality (Wilson, 2004), desiccation tolerance during seed development and maturation, and protection of seeds against drought damage were previously reported. For example, it was reported that the accumulation of compatible solutes such as sugars (non-structural sugars), including sucrose, raffinose, stachyose (Chen and Murata, 2002), and sucrose, hexoses, and sugar alcohols accumulation are related to osmotic stress tolerance (Streeter et al., 2001; Taji et al., 2002). It was explained that the accumulation of sugars was a result of starch hydrolysis and sugars conversion (Ingram et al., 1997), where sugars act as osmotica to protect specific macromolecules and stabilize membrane structures, protect cells during desiccation (Phillips et al., 2002), and prevent membrane fusion. In our experiment, the accumulation of raffinose oligosaccharides (RFOs) was higher 


\begin{tabular}{|c|c|c|c|c|c|c|c|c|}
\hline \multirow[t]{2}{*}{ Constituent } & $\mathbf{w}$ & DS & delta & $\%$ of $\mathbf{W}$ & $\mathbf{w}$ & DS & delta & $\%$ of $\mathbf{W}$ \\
\hline & \multicolumn{4}{|c|}{ Boggs } & \multicolumn{4}{|c|}{ NC-Roy } \\
\hline Protein & 42.2 & 43.7 & 1.5 & 3.6 & 41 & 43.7 & 2.7 & 6.6 \\
\hline Oil & 19.5 & 18.8 & -0.7 & -3.6 & 20.1 & 18.6 & -1.5 & -7.5 \\
\hline C18:1 & 20.2 & 25.4 & 5.2 & 25.7 & 20 & 25.4 & 5.4 & 27.0 \\
\hline C18:3 & 7.5 & 6.48 & -1.02 & -13.6 & 6.9 & 5.88 & -1.02 & -14.8 \\
\hline Sucrose & 3.5 & 2.28 & -1.22 & -34.9 & 3.6 & 2.25 & -1.35 & -37.5 \\
\hline Raffinose & 0.47 & 0.49 & 0.02 & 4.3 & 0.55 & 0.54 & -0.01 & -1.8 \\
\hline Stachyose & 3.3 & 4.07 & 0.77 & 23.3 & 3.3 & 4.85 & 1.55 & 47.0 \\
\hline Glucose & 2.1 & 1.23 & -0.87 & -41.4 & 1.7 & 1.56 & -0.14 & -8.2 \\
\hline \multirow[t]{2}{*}{ Fructose } & 0.94 & 0.52 & -0.42 & -44.7 & 0.9 & 0.51 & -0.39 & -43.3 \\
\hline & \multicolumn{4}{|c|}{ NO49646 } & \multicolumn{4}{|c|}{ NTCPR945 } \\
\hline Protein & 40.6 & 42.7 & 2.1 & 5.2 & 40 & 42.8 & 2.8 & 7.0 \\
\hline Oil & 20.8 & 20.6 & -0.2 & -1.0 & 21.6 & 20.5 & -1.1 & -5.1 \\
\hline C18:1 & 22.2 & 29.7 & 7.5 & 33.8 & 22.8 & 33.4 & 10.6 & 46.5 \\
\hline C18:3 & 6.5 & 5.97 & -0.53 & -8.2 & 6.3 & 5.6 & -0.7 & -11.1 \\
\hline Sucrose & 4.3 & 3.2 & -1.1 & -25.6 & 3.9 & 4.2 & 0.3 & 7.7 \\
\hline Raffinose & 0.52 & 0.6 & 0.08 & 15.4 & 0.52 & 0.7 & 0.18 & 34.6 \\
\hline Stachyose & 3.6 & 6.62 & 3.02 & 83.9 & 3.9 & 6.27 & 2.37 & 60.8 \\
\hline Glucose & 2.2 & 1.93 & -0.27 & -12.3 & 1.6 & 1.88 & 0.28 & 17.5 \\
\hline Fructose & 0.86 & 0.69 & -0.17 & -19.8 & 0.7 & 0.73 & 0.03 & 4.3 \\
\hline
\end{tabular}

The experiment was repeated twice and values are means of six replicates.

in SLW genotypes than in check genotypes under drought stress, and this is in agreement with other reports that many seeds accumulate considerable amounts of RFOs such as raffinose and stachyose under drought stress. For example, the high accumulation of RFOs such as raffinose and stachyose were thought to play a role in the acquisition of desiccation tolerance, and overexpression of galactinol synthase (catalyzes the first step in the biosynthesis of RFOs) led to higher accumulation of galactinol and raffinose and improved drought tolerance (Taji et al., 2002). In spite of the existing knowledge about RFOs, the mechanisms of how these sugars are involved in drought tolerance are still not fully understood (Chen and Murata, 2002; Bartels and Sunkar, 2005).

The higher accumulation of compatible solutes such as sucrose, hexoses, mannitol, sorbitol, and isotol (Gilmour et al., 2000; Streeter et al., 2001; Taji et al., 2002) and amino acids such as proline, glycine, and betaine to maintain turgor and stabilize proteins and cell structures (Yancey et al., 1982; Burg et al., 1996) were previously reported. The ability to maintain higher $\mathrm{Ca}$ and $\mathrm{K}$ in seeds in SLW genotypes than the checks may indicate that both $\mathrm{Ca}$ and $\mathrm{K}$ constitute the main cations in homeostasis regulation under drought stress, and since $\mathrm{K}$ is a quite mobile cation (Marschner, 2012), K movement from leaves to seed occurred under drought stress. The decrease of $\mathrm{K}$ in checks in DS compared with $\mathrm{W}$ treatment may be due to inability of these genotypes to maintain $\mathrm{K}$ concentration in their seed probably due to due lack of homeostasis regulation and water conservation. This explanation could partially be supported by the lower water potential observed in the check phenotypes compared with the SWL genotypes under drought, resulting in possible reduction in $\mathrm{K}$ uptake and movement of $\mathrm{K}$ from leaves to seed.

Under severe stress (soil water potential - $199 \mathrm{kPa}$ ), K in leaves and seed was significantly lower than under moderate drought stress (data not shown), indicating that the mobility can only occur up to a certain drought stress level. Since both $\mathrm{K}$ and $\mathrm{B}$ had clear responses (higher accumulations in SLW genotypes than the checks under drought stress), to further investigate their dynamics in leaves and seed under severe drought, foliar $\mathrm{K}$ and $\mathrm{B}$ were applied to SLW genotypes only. Foliar $\mathrm{K}$ at a rate of $1.75 \%$ as $\mathrm{K}_{2} \mathrm{SO}_{4}$ to SLW genotypes resulted in higher $\mathrm{K}$ in leaves and seeds under moderate drought stress ( -90 to $-100 \mathrm{kPa}$ ), but only a small increase in leaves and no significant increase in seeds under severe drought stress $(-199 \mathrm{KPa})$ (data not shown). Foliar application of B to SLW genotypes at a rate of $1.1 \mathrm{~kg} \mathrm{ha}^{-1}$ as $\mathrm{H}_{3} \mathrm{BO}_{3}$ resulted in higher $\mathrm{B}$ in leaves and seed and higher glucose, fructose, and sucrose under wellwatered and moderate drought stress conditions, but not in severe drought stress (data not shown). It must be noted that the rate of increase of B during R5-R6 in leaves and seeds, which resulted from foliar $B$ application, was lower than that of $K$ increases, perhaps due to limited mobility of $\mathrm{B}$ in the soybean phloem compared with $\mathrm{K}$, which is quite mobile. Foliar B application under severe drought stress did not result in higher B in seeds of SLW genotypes, suggesting that B movement of B from leaves to seed under drought stress is restricted even when foliar $B$ is applied.

\section{NITROGEN FIXATION AND ASSIMILATION, AND LEAF WATER POTENTIAL}

The differences between genotypes for nitrogen fixation and leaf nitrogen assimilation under well watered conditions could be due to genotypic differences rather than SLW trait, as the SLW trait may be expressed only under drought stress conditions. The lower rates of nitrogen fixation and nodule nitrogen assimilation under drought conditions in checks compared with SLW genotypes could be due to drought stress effects and lower nutrient uptakes as a result, especially $\mathrm{K}, \mathrm{B}, \mathrm{Fe}, \mathrm{Cu}$, and $\mathrm{Zn}$ that are indirectly affect nitrogen fixation. Also, the check genotypes may lack the ability for homeostasis regulation and water conservation, resulting in inhibition of nitrogen fixation and nodule nitrogen assimilation compared with the SLW genotypes. The higher nitrogen fixation and nodule nitrogen assimilation in SLW genotypes than the check genotypes suggested that nitrogen fixation and nodule nitrogen assimilation are more indicative in drought stress than is leaf nitrogen assimilation. The inhibition of nitrogen fixation and nitrogen assimilation under drought stress is due to the negative effects of drought on the activity of nitrogenase and nitrate reductase, although nitrogenase is more sensitive than nitrate reductase (Purcell and King, 1996). Previous research reported that mechanisms involved in the physiological response of nitrogen fixation to drought included carbon shortage, nodule carbon metabolism, oxygen limitation, and feedback of nitrogen fixation 
products (Serraj et al., 1999; Serraj, 2003) such as amides (mainly asparagine) and ureides (allantoin and allantoic acid) (Schubert et al., 1995).

The higher leaf water potential in the SLW genotypes compared with the check genotypes may indicate that leaf water potential could be involved in the SLW trait as leaf water potential may be related to stomatal conductance's role to restrict water loss and conserve water, supporting previous research. For example, crop response to water deficit involves physiological changes to minimize water loss such as closing stomata and reducing leaf surface area (O'Toole and Moya, 1978) and canopy wilting (Lawlar and Cornic, 2002). However, canopy wilting has not been well studied (Lawlar and Cornic, 2002; King et al., 2009), and previous research showed that soybean genotypes differ in canopy wilting under water deficit (Sloane et al., 1990).

\section{RESPONSE MECHANISMS OF SLOW-WILTING TRAIT TO DROUGHT TOLERANCE}

When the mechanisms of SLW trait were evaluated, it was suggested that drought tolerant genotype had higher soil moisture during drought compared with a fast-wilting genotype due to low rates of transpiration and decline in water use in the whole plant during soil water deficit (Sloane et al., 1990; Fletcher et al., 2007; King et al., 2009; Sadok and Sinclair, 2009). The ability to conserve soil moisture by lowering transpiration rate in SLW genotypes was to maintain turgor pressure compared with fastwilting genotypes Fletcher et al., 2007; Charlson et al., 2009; King et al., 2009; Ries et al., 2012. Hufstetler et al. (2007) investigated three physiological traits (water use efficiency, decline of water use in the whole plant during drought stress, and low leaf epidermal conductance). They conducted two greenhouse experiments and compared these three traits in six soybean plant introductions, eight breeding lines, and nine cultivars during vegetative growth. During these experiments, the water use efficiency (ratio of total plant dry weight to total water used), low leaf epidermal conductance, and the critical soil water content at which each plant began to reduce its water use were determined. They found significant variation among the tested genotypes for the three traits. They found a negative correlation between water use efficiency and leaf epidermal conductance across genotypes, and adapted genotypes had higher water use efficiency and lower leaf epidermal conductance. However, PI 471938 and its progeny N98-7264 did not follow the same trend.

King et al. (2009) studied the slow-wilting trait in a two-years field experiment in 19 soybean genotypes among which PI 416937 and PI 471938 were among the slowest wilting genotypes, and breeding lines 93705-34 and 93705-95 were among the fastest wilting. They found in a separate field experiment that volumetric soil water content was higher in slow-wilting PI 416937 than fast-wilting 93705-95; however, wilting in both genotypes responded similarly to soil water content. They also studied the SLW trait under growth chamber conditions and found that transpiration was reduced due to drought stress similarly for slowand fast-wilting genotypes, and wilting response to soil water was the same for slow-wilting PI 416937 and fast-wilting genotypes 93705-34 and A5959. Slow-wilting 93705-36 exhibited wilting at lower soil water content than PI416937, 93705-34, and A5959. King et al. (2009) concluded that more than one mechanism may be involved in slow wilting. Also, Sloane et al. (1990), using a slow-wilting genotype PI 416937 and fast-wilting cultivar Forrest, found that water stress reduced leaf water potential equally for both genotypes, but PI 416937 maintained lower levels of solute potential and higher pressure potential and relative water content than Forrest. They suggested that under water stress PI 416937 may accumulate more solutes in leaves than Forrest, and concluded that PI 416937 may be an important source of drought tolerance for breeding programs.

\section{CONCLUSION}

The physiological mechanisms explaining the response of the slow-wilting trait to drought stress are complex (Charlson et al., 2009), still not well understood (King et al., 2009), and more than one mechanism could be involved (Hufstetler et al., 2007). The higher accumulation of specific minerals such as $\mathrm{K}, \mathrm{Ca}, \mathrm{B}, \mathrm{Na}$, organic compounds such as sucrose, raffinose and stachyose, and oleic acid under drought stress in SLW genotypes could be one of the mechanisms used to maintain cell turgor, conserve water, and achieve osmoregulation under drought stress. The contribution of $\mathrm{S}$, and micro-nutrients such as $\mathrm{B}, \mathrm{Mn}, \mathrm{Cu}$, and $\mathrm{Zn}$ is still not known, and could be important as these minerals are involved in several enzymatic physiological and biochemical processes. Nitrogen metabolism, especially nitrogen fixation is more sensitive to drought than nitrogen assimilation, supporting previous findings. Leaf water potential could be used as a drought tolerance indicator in slow-wilting genotype selection as slow wilting genotypes exhibited higher leaf water potential than their equivalent checks. Higher leaf water potential in SLW genotypes could indicate that the SWL genotypes conserve water by maintaining more water in the leaves, and maintaining adequate leaf and seed nutrients, and achieve homeostasis. Leaf and seed nutrients exhibited higher accumulation in SLW genotypes, and this knowledge could help soybean breeders to select for drought tolerance.

\section{ACKNOWLEDGMENTS}

We thank Dr. Thomas E. Carter for consultation and for providing us with seeds for the checks and the slow-wilting soybean genotypes used in this study. We also thank Sandra Mosley for assistance in performing laboratory procedures. This research was funded by United States Department of Agriculture, Agricultural Research Service project number 6402-21220-01200D. The U.S. Department of Agriculture (USDA) prohibits discrimination in all its programs and activities on the basis of race, color, national origin, age, disability, and where applicable, sex, marital status, familial status, parental status, religion, sexual orientation, genetic information, political beliefs, reprisal, or because all or part of an individual's income is derived from any public assistance program. (Not all prohibited bases apply to all programs.) Persons with disabilities who require alternative means for communication of program information (Braille, large print, audiotape, etc.) should contact USDA's TARGET Center at (202) 720-2600 (voice and TDD). To file a complaint of discrimination, write to USDA, Director, Office of Civil Rights, 1400 Independence Avenue, S.W., Washington, D.C. 20250-9410, or call (800) 795-3272 (voice) or (202) 720-6382 (TDD). USDA is an equal opportunity provider and employer. 


\section{REFERENCES}

Ackerson, R. C. (1985). Osmoregulation in cotton in response to waterstress. 3. Effects of phosphorus fertility. Plant Physiol. 77, 309-312. doi: 10.1104/pp.77.2.309

Analytical Methods Committee. (1959). Analysts. Vol 84. London: Her Majesty's Stationery Office.

Andersen, M. N., Jensen, C. R., and Lösch, R. (1992). The interaction effects of potassium and drought in field-grown barley. 1. Yield, water-use efficiency and growth. Acta Agric. Scand. Sect. B Soil Plant Sci. 42, 34-44.

AOAC (Association of Official Analytical Chemists). (1990a). "Method 988.05," in Official methods of analysis, 15th Edn., ed K. Helrich (Arlington, VA: AOAC), 70.

AOAC (Association of Official Analytical Chemists). (1990b). "Method 920.39," in Official methods of Analysis, 15th Edn., ed K. Helrich (Arlington, VA: AOAC), 79.

Bandemer, S. L., and Schaible, P. J. (1944). Determination of iron. A study of the o-phenanthroline method. Ind. Eng. Chem. Anal. Ed. 16, 317-319. doi: $10.1021 / 1560129 \mathrm{a} 013$

Bartels, D., and Sunkar, R. (2005). Drought and salt tolerance in plants. Crit. Rev. Plant. Sci. 24, 23-58. doi: 10.1080/07352680590910410

Bellaloui, N., Hu, Y., Mengistu, A., Kassem, M. A., and Abel, C. A. (2013). Effects of foliar boron application on seed composition, cell wall boron, and seed $\delta^{15} \mathrm{~N}$ and $\delta{ }^{13} \mathrm{C}$ isotopes in water-stressed soybean plants. Front. Plant Sci. 4, 270-281. doi: $10.3389 /$ fpls. 2013.00270

Bellaloui, N., and Mengistu, A. (2008). Seed composition is influenced by irrigation regimes and cultivar differences in soybean. Irrig. Sci. 26, 261-268. doi: 10.1007/s00271-007-0091-y

Bellaloui, N., Mengistu, A., Zobiole, L. H. S., and Shier, W. T. (2012). Resistance to toxin-mediated fungal infection: role of lignins, isoflavones, other seed phenolics, sugars, and boron in the mechanism of resistance to charcoal rot disease in soybean. Toxin Rev. 31, 16-26. doi: 10.3109/15569543.2012.691150

Bellaloui, N., Reddy, K. N., Gillen, A. M., and Abel, C. A. (2010a). Nitrogen metabolism and seed composition as influenced by foliar boron application in soybean. Plant Soil 336, 143-155. doi: 10.1007/s11104-010-0455-6

Bellaloui, N., Smith, J. R., Gillen, A. M., and Ray, J. D. (2010b). Effect of maturity on seed sugar in the early soybean production system as measured on near-isogenic soybean lines. Crop Sci. 49, 608-620. doi: 10.2135/cropsci2008. 04.0192

Bellaloui, N., Smith, J. R., Gillen, A. M., and Ray, J. D. (2011). Effects of maturity, genotypic background, and temperature on seed mineral composition in near-isogenic soybean lines in the early soybean production system. Crop Sci. 51, 1161-1171. doi: 10.2135/cropsci2010.04.0187

Bellaloui, N., Smith, J. R., Ray, J. D., and Gillen, A. M. (2009). Effect of maturity on seed composition in the early soybean production system as measured on nearisogenic soybean lines. Crop Sci. 49, 608-620. doi: 10.2135/cropsci2008.04.0192

Boydak, E., Alpaslan, M., Hayta, M., Gercek, S., and Simsek, M. (2002). Seed composition of soybeans grown in the Harran region of Turkey as affected by row spacing and irrigation. J. Agric. Food Chem. 50, 718-720. doi: 10.1021/ jf0255331

Brück, H., Payne, W. A., and Sattelmacher, B. (2000). Effects of phosphorus and water supply on yield, transpirational water-use efficiency, and carbon isotope discrimination of pearl millet. Crop Sci. 40, 120-125. doi: 10.2135/cropsci2000.401120x

Burg, M. B., Kwon, E. D., and Kultz, D. (1996). Osmotic regulation of gene expression. FASEB J. 10, 1598-1606.

Caba, J. M., Lluch, C., and Ligero, F. (1995). Distribution of nitrate reductase activity in Vicia faba: effect of nitrate and plant genotype. Physiol. Plant. 93, 667-672. doi: 10.1111/j.1399-3054.1995.tb05115.x

Cavell, A. J. (1955). The colorimetric determination of phosphorus in plant materials. J. Sci. Food Agric. 6, 479-480. doi: 10.1002/jsfa.2740060814

Charlson, D. V., Bhatnagar, S., King, C. A., Ray, J. D., Sneller, C. H., Carter, Jr. T. E., et al. (2009). Polygenic inheritance of canopy wilting in soybean [Glycine $\max ($ L.) Merr.]. Theor. Appl. Genet. 119, 587-594. doi: 10.1007/s00122-0091068-4

Chen, T. H., and Murata, N. (2002). Enhancement of tolerance of abiotic stress by metabolic engineering of betaines and other compatible solutes. Curr. Opin. Plant Biol. 5, 250-257. doi: 10.1016/\$1369-5266(02)00255-8

Dordas, C. (2006). Foliar boron application improves seed set, seed yield, and seed quality of alfalfa. Agron. J. 98, 907-913. doi: 10.2134/agronj2005.0353
Dordas, C., Apostolides, G., and Goundra, O. (2007). Boron application affects seed yield and seed quality of sugar beets. J. Agric. Sci. 145, 377-384. doi: $10.1017 /$ S0021859607006879

Fehr, W. R., and Caviness, C. E. (1977). Stages of Soybean Development. Iowa Agric. Home Econ. Exp. Stn. Spec. Rep., Vol. 80. Ames, IA: Iowa State University.

Fletcher, A. L., Sinclair, T. R., and Allen, L. H. Jr. (2007). Transpiration responses to vapor pressure deficit in well watered slow-wilting and commercial soybean. Environ. Exp. Bot. 61, 145-151. doi: 10.1016/j.envexpbot.2007.05.004

Furlan, A., Llanes, A., Luna, V., and Castro, S. (2012). Physiological and biochemical responses to drought stress and subsequent rehydration in the symbiotic association peanut-Bradyrhizobium sp. Agronomy 2012:318083. doi: $10.5402 / 2012 / 318083$

Garg, B. K., Burman, U., and Kathju, S. (2004). The influence of phosphorus nutrition on the physiological response of moth bean genotypes to drought. J. Plant Nutr. Soil Sci. 167, 503-508. doi: 10.1002/jpln.200320368

Gilmour, S. J., Seblot, A. M., Salazar, M. P., Everard, J. D., and Thomashow, M. F. (2000). Overexpression of the Arabidopsis CBF3 transcriptional activator mimics multiple biochemical changes associated with cold acclimation. Plant Physiol. 124, 1854-1865. doi: 10.1104/pp.124.4.1854

Hardy, R. W. F., Holsten, D., Jackson, E. K., and Burns, R. C. (1968). The acetyleneethylen eassay for nitrogen fixation: laboratory and field evaluation. Plant Physiol. 43, 1185-1207. doi: 10.1104/pp.43.8.1185

Hsiao, T. C. (1973). Plant responses to water stress. Annu. Rev. Plant Physiol. 24, 519-570. doi: 10.1146/annurev.pp.24.060173.002511

$\mathrm{Hu}$, Y., and Schmidhalter, U. (2005). Drought and salinity: a comparison of their effects on mineral nutrition of plants. J. Plant Nutr. Soil Sci. 168, 541-549. doi: 10.1002/jpln.200420516

Hufstetler, E. V., Boerma, H. B., Carter, Jr. T. E., and Earl, H. J. (2007). Genotypic variation for three physiological traits affecting drought tolerance in soybean. Crop Sci. 47, 25-35. doi: 10.2135/cropsci2006.04.0243

Ingram, J., Chandler, J. W., Gallagher, L., Salamini, F., and Bartels, D. (1997). Analysis of cDNA clones encoding sucrose-phosphate synthase in relation to sugar inter conversions associated with dehydration in the resurrection plant Craterostigma plantagineum Hochst. Plant Physiol. 115, 113-121. doi: 10.1104/pp.115.1.113

John, M. K., Chuah, H. H., and Neufeld, J. H. (1975). Application of improved azomethine-H method to the determination of boron in soils and plants. Anal. Lett. 8, 559-568. doi: 10.1080/00032717508058240

Kanayama, Y., Kimura, K., Nakamura, Y., and Ike, T. (1999). Purification and characterization of nitrate reductase from nodule cytosol of soybean plants. Physiol. Plant. 105, 396-401. doi: 10.1034/j.1399-3054.1999.105302.x

King, C. A., Purcell, L. C., and Brye, K. R. (2009). Differential wilting among soybean genotypes in response to water deficit. Crop Sci. 49, 290-298. doi: 10.2135/cropsci2008.04.0219

Klepper, L., and Hageman, R. H. (1969). The occurrence of nitrate reductase in apple leaves. Plant Physiol. 44, 110-114. doi: 10.1104/pp.44.1.110

Knight, H., Trewavas, A. J., and Knight, M. R. (1997). Calcium signaling in Arabidopsis thaliana responding to drought and salinity. Plant J. 12, 1067-1078. doi: 10.1046/j.1365-313X.1997.12051067.x

Lawlar, D. W., and Cornic, G. (2002) Photosynthetic carbon assimilation and associated metabolism in relation to water deficits in higher plants. Plant Cell Environ. 25, 275-294. doi: 10.1046/j.0016-8025.2001.00814.x

Loeppert, R. L., and Inskeep, W. P. (1996). "Colorimetric determination of ferrous iron and ferric iron by the 1,10-phenanthroline method," in Methods of Soil Analysis: Part 3. Chemical Methods, ed J. M. Bigham (Madison, WI: SSSA), 659-661.

Lohse, G. (1982). Microanalytical azomethine-H method for boron determination in plant tissue. Comm. Soil Sci. Plant Anal. 13, 127-134. doi: 10.1080/00103 628209367251

Ma, Q., Turner, D. W., Levy, D., and Cowling, W. A. (2004). Solute accumulation and osmotic adjustment in leaves of Brassica oilseeds in response to soil water deficit. Aust. J. Agric. Res. 55, 939-945. doi: 10.1071/AR03183

Marschner, P. (2012). Marschner's Mineral Nutrition of Higher Plants. 3rd Edn. San Diego, CA: Academic Press.

McLaughlin, S. B., and Wimmer, R. (1999). Transley Review No. 104, Calcium physiology terrestrial ecosystem processes. New Phytol. 142, 373-417. doi: 10.1046/j.1469-8137.1999.00420.x

Mengel, K., and Kirkby, E. A. (1982). Principles of Plant Nutrition. 3rd Edn. Worblaufen-Bern: Int. Potash Inst. 
Mengistu, A., Smith, J. R., Bellaloui, N., Paris, R. L., and Wrather, J. A. (2010). Irrigation and time of harvest: effects on evaluation of selected soybean accessions against Phomopsis longicolla. Crop Sci. 50, 2055-2064. doi: 10.2135/cropsci2009.11.0657

Morgan, J. M. (1992). Osmotic components and properties associated with genotypic differences in osmoregulation in wheat. Aust. J. Plant Physiol. 19, 67-76. doi: 10.1071/PP9920067

O’Toole, J. C., and Moya, T. B. (1978). Genotypic variation in maintenance of leaf water potential in rice. Crop Sci. 18, 873-876.

Phillips, J. R., Oliver, M. J., and Bartels, D. (2002). "Molecular genetics of desiccation and tolerant systems," in Desiccation and Survival in Plants: Drying without Dying, eds M. Black and H. Pritchard (Wallingford, CAB International), 319-341. doi: 10.1079/9780851995342.0319

Pinkerton, A., and Simpson, J. R. (1986). Interactions of surface drying and subsurface nutrients affecting plant-growth on acidic soil profiles from an old pasture. Aust. J. Exp. Agric. 26, 681-689. doi: 10.1071/EA9860681

Purcell, L. C., and King, C. A. (1996). Drought and nitrogen source effects on nitrogen nutrition, seed growth, and yield in soybean. J. Plant Nutr. 19, 969-993. doi: $10.1080 / 01904169609365173$

Rasnick, M. (1970). Effect of mannitol and polyethylene glycol on phosphorus uptake by maize plants. Ann. Bot. 34, 497-502.

Ren, C., Bilyeu, K. D., and Beuselinck, P. R. (2009). Composition, vigor, and proteome of mature soybean seeds developed under high temperature. Crop Sci. 49, 1010-1022. doi: 10.2135/cropsci2008.05.0247

Ries, L. L., Purcell, L. C., Carter, T. E. Jr., Edwards, J. T., and King, C. A. (2012). Physiological traits contributing to differential canopy wilting in soybean under drought. Crop Sci. 52, 272-281. doi: 10.2135/cropsci2011.05.0278

Sadok, W., and Sinclair, T. R. (2009). Genetic variability of transpiration response to vapor pressure deficit among soybean cultivars. Crop Sci. 49, 955-960. doi: 10.2135/cropsci2008.09.0560

Sangakkara, U. R., Frehner, M., and Nösberger, J. (2001). Influence of soil moisture and fertilizer potassium on the vegetative growth of mungbean (Vigna radiata $\mathrm{L}$. Wilczek) and cowpea (Vigna unguiculata L. Walp). J. Agron. Crop Sci. 186, 73-81. doi: 10.1046/j.1439-037X.2001.00433.x

SAS Institute. (2001). SAS 9.1 TS Level 1M3, Windows version 5.1.2600. Cary, NC: SASInstitute.

Sawwan, J., Shibli, R. A., Swaidat, I., and Tahat, M. (2000). Phosphorus regulates osmotic potential and growth of African violet under in vitro-induced water deficit. J. Plant Nutr. 23, 759-771. doi: 10.1080/01904160009382057

Scherer, H. W. (2001). Sulphur in crop production-Invited paper. Eur. J. Agron. 14, 81-111. doi: 10.1016/S1161-0301(00)00082-4

Schroeder, J. I., Kwak, J. M., and Allen, G. J. (2001). Guard cell abscisic acid signalling and engineering drought hardiness in plants. Nature 410, 327-330. doi: $10.1038 / 35066500$

Schubert, S., Serraj, R., Plies-Balzer, E., and Mengel, K. (1995). Effect of drought stress on growth, sugar concentrations and amino acid accumulation in N2fixing alfalfa. J. Plant Physiol. 146, 541-546. doi: 10.1016/S0176-1617(11) 82021-3

Serraj, R. (2003). Effects of drought stress on legume symbiotic nitrogen fixation: physiological mechanisms. Indian J. Exp. Biol. 41, 1136-41. Avaliable online at: http://oar.icrisat.org/3927/1/IndianJournalofExpBiology_ 41_1136-1146_2003.pdf

Serraj, R., Sinclair, T. R., and Purcell, L. C. (1999). Symbiotic N2 fixation response to drought. J. Exp. Bot. 50, 143-155. doi: 10.1093/jxb/50.331.143
Sloane, R. J., Patterson, R. P., and Carter, T. E. Jr. (1990). Field drought tolerance of a soybean plant introduction. Crop Sci. 30, 118-123. doi: 10.2135/cropsci1990.0011183X003000010027x

Smith, J. R., Mengistu, A., Nelson, R. L., and Paris, R. L. (2008). Identification of soybean accessions with high germinability in high-temperature environments. Crop Sci. 48, 2279-2288. doi: 10.2135/cropsci2008.01.0026

Streeter, J. G., Lohnes, D. G., and Fioritto, R. J. (2001). Pattern of pinitol accumulation in soybean plants and relationships to drought tolerance. Plant Cell Environ. 24, 429-438. doi: 10.1046/j.1365-3040.2001.00690.x

Sze, H., Liang, F., Hwang, I., Curran, A. C., and Harper, J. F. (2000). Diversity and regulation of plant $\mathrm{Ca} 2+$ pumps: insights from expression in yeast. Annu. Rev. Plant Physiol. Plant Mol. Biol. 51, 433-462. doi: 10.1146/annurev.arplant. 51.1.433

Taji, T., Ohsumi, C., Iuchi, S., Seki, M., Kasuga, M., Kobayashi, M., et al. (2002). Important roles of drought- and cold-inducible genes for galactinol synthase in stress tolerance in Arabidopsis thaliana. Plant J. 29, 417-426. doi: 10.1046/ j.0960-7412.2001.01227.x

Wei, W. X., Bilsborrow, P. E., Hooley, P., Fincham, D. A., Lombi, E., and Forster, B. P. (2003). Salinity induced differences in growth, ion distribution and partitioning in barley between the cultivar Maythorpe and its derived mutant golden promise. Plant Soil 250, 183-191. doi: 10.1023/A:1022832107999

Wilcox, J. R., and Shibles, R. M. (2001). Interrelationships among seed quality attributes in soybean. Crop Sci. 41, 11-14. doi: 10.2135/cropsci2001. $41111 \mathrm{x}$

Wilson, R. F. (2004). "Seed composition," in Soybeans: Improvement, Production, and Uses, eds H. Boerma and J. E. Specht (Madison, WI: American Society of Agronomy, Crop Science Society of America, and Soil Science Society of America), 621-668.

Yancey, P. H., Clark, M. E., Hand, S. C., Bowlus, R. D., and Somero, G. N. (1982). Living with water stress: evolution of osmolyte systems. Science 217, 1214-1222. doi: $10.1126 /$ science.7112124

Zablotowicz, R. M., Focht, D. D., and Cannell, G. H. (1981). Nodulation and $\mathrm{N}$ fixation of field grown California cowpeas as influenced by irrigated and droughted conditions. Agron. J. 73, 9-12. doi: 10.2134/agronj1981. $00021962007300010003 x$

Conflict of Interest Statement: The authors declare that the research was conducted in the absence of any commercial or financial relationships that could be construed as a potential conflict of interest.

Received: 27 September 2013; accepted: 19 November 2013; published online: 10 December 2013.

Citation: Bellaloui N, Gillen AM, Mengistu A, Kebede H, Fisher DK, Smith JR and Reddy KN (2013) Responses of nitrogen metabolism and seed nutrition to drought stress in soybean genotypes differing in slow-wilting phenotype. Front. Plant Sci. 4:498. doi: $10.3389 / \mathrm{fpls} .2013 .00498$

This article was submitted to Plant Physiology, a section of the journal Frontiers in Plant Science.

Copyright (C) 2013 Bellaloui, Gillen, Mengistu, Kebede, Fisher, Smith and Reddy. This is an open-access article distributed under the terms of the Creative Commons Attribution License (CC BY). The use, distribution or reproduction in other forums is permitted, provided the original author(s) or licensor are credited and that the original publication in this journal is cited, in accordance with accepted academic practice. No use, distribution or reproduction is permitted which does not comply with these terms. 